\title{
Article \\ Factors Influencing Adoption of Compost Made from Organic Fraction of Municipal Solid Waste and Purchasing Pattern: A Survey of Italian Professional and Hobbyist Users
}

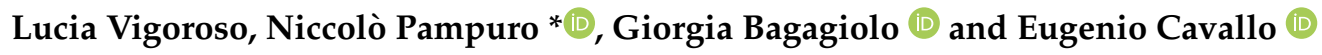 \\ Institute of Sciences and Technologies for Sustainable Energy and Mobility (STEMS), National Research Council \\ of Italy (CNR), Strada delle Cacce, 73-10135 Torino, Italy; lucia.vigoroso@stems.cnr.it (L.V.); \\ giorgia.bagagiolo@stems.cnr.it (G.B.); eugenio.cavallo@stems.cnr.it (E.C.) \\ * Correspondence: niccolo.pampuro@stems.cnr.it
}

\section{check for} updates

Citation: Vigoroso, L.; Pampuro, N.; Bagagiolo, G.; Cavallo, E. Factors Influencing Adoption of Compost Made from Organic Fraction of Municipal Solid Waste and Purchasing Pattern: A Survey of Italian Professional and Hobbyist Users. Agronomy 2021, 11, 1262. https:// doi.org/10.3390/agronomy11061262

Academic Editors: Andrea Peruzzi, Marco Fontanelli and Michel Pirchio

Received: 31 May 2021

Accepted: 16 June 2021

Published: 21 June 2021

Publisher's Note: MDPI stays neutral with regard to jurisdictional claims in published maps and institutional affiliations.

Copyright: (c) 2021 by the authors. Licensee MDPI, Basel, Switzerland. This article is an open access article distributed under the terms and conditions of the Creative Commons Attribution (CC BY) license (https:/ / creativecommons.org/licenses/by/ $4.0 /)$.
Abstract: Composting represents an alternative for the management of the organic fraction from municipal waste. However, the adoption of compost made from municipal waste is not yet widespread across all European countries, including Italy. Being 'professional' (i.e., farmers and gardeners) and 'hobbyists' the most representative categories of compost buyers in Italy, this study investigated their attitude toward municipal waste compost adoption and their purchasing pattern, pointing out criticalities and strategies to promote a wider use of this kind of compost. For the two categories of users, frequency of use of different information, buying habits, opinions on marketing issues, and factors which encourage compost utilization were investigated. The 'professionals' and 'hobbyists' reported different purchasing behaviors in terms of quantity, frequency, and preferred packaging format. The capability of compost from municipal waste to improve soil characteristics and its low environmental impact were identified as the most significant aspects for users, while availability of economic subsidies was not a determining factor for municipal waste compost adoption. With regard to the information sources, the broader use of personal communication channels like peers' suggestions may have influence on compost adoption pointing out how social influence can promote sustainable behavior and influence users' purchasing choices.

Keywords: circular economy; compost users; information sources; purchasing pattern; recycle municipal waste

\section{Introduction}

Municipal waste management and disposal are complex issues characterized by relevant environmental and social impacts [1]. According to statistics, in the EU-28, about 242.3 million tons of waste were produced in the 2015 [2]: 29.4\% of the whole waste was recycled, $16.8 \%$ was composted, $27.5 \%$ was destined for incineration, and $26.3 \%$ was disposed in landfills [2]. In details, considering the Italian context, in 2016, 30.1 million tons of municipal waste were produced: $45 \%$ was recycled (of which only $19 \%$ consists of organic fraction), $18 \%$ of waste was sent to incinerators, $26 \%$ was disposed in landfills, about $2 \%$ was sent to facilities to produce energy, and the remaining $9 \%$ includes waste managed by domestic composting and waste produced by mechanical-biological treatment facilities [2]. Overall, it is possible to affirm that the Union's economy sent millions of tons of potential secondary raw materials to landfills, missing the opportunity for improving the resource efficiency through the application of the paradigm of the circular economy [3].

The circular economy (CE) business model represents a more sustainable alternative to the current "linear economic system" which is based on the concept of "take, make, and dispose" [4]. Whereas, the CE business model is based on a closed-loop in which the output of a system can be the input for a new productive process [5]. Moreover, this model is mainly influenced by the principle of the cradle-to-cradle design approach and zero-waste 
philosophy [6,7]. In recent years, the CE business model has been gradually encouraged [8] in several European countries (e.g., France, the United Kingdom, Sweden, Finland, Holland, and Italy [9]) and in other worldwide countries (such as China, Japan, and Canada [10]). The CE business model defines technologies to reduce leakages, environmental pollution, input and costs in the production system by implementing Resource Recovery and Reuse (RRR) measures and recycling the waste [11].

Following the above-mentioned principles, composting organic fraction of municipal solid waste (OFMSW) and obtained from separate collection, represents an efficient alternative for the management of the organic fraction of waste, which includes food waste, kitchen waste, leaf, grass clippings, flower trimmings, and yard waste (lignocellulosicbased materials explicitly grass off cuts and straw, leaves, weeds, bush and tree trimmings, whose production varies depending on the season) $[12,13]$. Indeed, composting can reduce the landfill disposal and, at the same time, apply the composted material to agricultural lands [14-16], thus recycling agronomic macronutrients (nitrogen, phosphorus, and potassium) and maintaining the organic carbon content in the soil.

Composting is an aerobic process that involves the decomposition of organic matter $(\mathrm{OM})$ under controlled temperature, moisture, and oxygen conditions leading to a stabilized final product, free of phytotoxicity and pathogens and with specific humic properties [17-20]. Composting also implies organic matter deodorization and sanitization regarding weeds and pathogens [21]. Composted OM could be reused as a new resource material, such as soil fertilizer and conditioner, substituting the more costly chemical fertilizer and reducing the total costs of crop production [22-25]. Alternative use of composted material in environmental engineering has also been investigated [26].

Despite the numerous advantages and versatility of uses of compost, still little is known about the factors that might hinder or encourage the adoption of this product [27], in particular with regard to compost derived from municipal waste.

As reported by some studies $[27,28]$ limiting factors could be related to: the type of farming practices and productive system, the available resources (e.g., financial resources and workforce), but also aspects related with human factors such as age, level of education, previous working experience, access to information and personal perceptions. For example, as indicated by Camacho et al. [29], operators are reluctant with regard to composting practice for the mere beliefs that municipal waste is dirty, has a bad smell, and may present traces of heavy metals that can cause diseases.

With regard to drivers of OFMSW compost adoption, some studies reported that positive environmental attitudes may influence the intention to use sustainable products as compost [30,31]. Tamas et al. [31] stated that the favorable compost properties could be promoted through dissemination of information, emotionally persuasive arguments and social pressure, meaning the importance of other people's opinions and how they perceive the moral norms regarding composting habits. It is also important to consider that users often observe the habits of society before adopting a new specific behavior [32]. At the same time, a report by the European Commission [33] highlighted that widespread dissemination of information, including personalized letters, presentations in public places, advertisements in newspapers, television and radio, and the involvement of local and municipal authorities, increases the propensity to adopt new practices, such as compost application.

Despite the evidence related to the positive impacts on soil fertility, the adoption of compost made from municipal waste is not yet widespread across all European countries, including Italy, since many users still associate this material with environmental and health hazards because of possible soil contamination [28,34]. Only a few previous studies focused on willingness to use compost [27,35-37], demonstrating that its benefits are not widely known by all the potential users [15]. Among these users, farmers and hobbyists can be considered as the potential large-volume users of OFMSW compost [15,35]. In addition, accordingly to previous estimates of the potential use of compost in Italy, agriculture (considering vegetable growing, fruit growing, and forage crop production) represents 
the sector with the most significant potential market, currently including only $13 \%$ of the market share; whereas the hobby sector covers nearly $68 \%$ of the market share [38].

Notwithstanding all the previous considerations, to our knowledge, OFMSW compost has received little attention. In particular, the Italian operators' perception of compost properties has been under-investigated [26]. Together with the need to develop compost facilities to transform municipal waste into a new reusable resource, it is also fundamental in establishing a continuous demand market and understand the role of users' behavior in the development of the CE business models [34]. Hence, encouraging the adoption of OFMSW compost among potential users can have a significant effect on the development of a sustainable bio-economy because raw materials used for composting can be considered an unlimited input [34].

In this context, the present study aimed to investigate Italian users' purchasing patterns of OFMSW compost and find out which factors influence its utilization among current users. The study was carried out with a sample of Italian users, delineating 'professionals' (i.e., farmers and gardeners) and 'hobbyists' (i.e., those practicing gardening, horticulture, or farming just as a hobby) as the most representative categories among compost buyers. Comprehension of users' perceptions could be useful to point out some current perceived criticalities towards OFMSW compost adoption. Thus, this study could provide tips for marketing strategies or information campaigns to promote more extensive use of OFMSW compost, especially among users in the Italian context, where the adoption of this type of compost is still quite uncommon.

\section{Materials and Methods}

\subsection{Participants Recruitment}

Participants were randomly recruited among the visitors of the 24th Ecomondo Green Technology Expo (3-6 November 2019) in Rimini, which is one of the most prominent Italian and European green and circular economy exhibition, focused on the reuse of raw materials, energy, and sustainable development, with more than 100,000 visitors every year. This type of event represents an excellent opportunity to perform survey investigations and data collection among groups of municipal waste compost users $[26,39,40]$. To be recruited, participants needed to be familiar with this type of compost obtained from OFMSW treatment. Respondents were selected among Italian visitors who had experience in the use of compost made from OFMSW. Both 'professionals' and 'hobbyists' were recruited [41,42]. In details, the group of professionals included participants interested in using municipal waste compost prompted by professional perspective (i.e., working as farmers and gardeners), whereas the hobbyists group included participants prompted by personal and non-commercial interest (i.e., 'hobby farmers' and those practicing gardening and horticulture just as a hobby). 'Hobby farmers' were users who are external to agricultural activity in terms of time and income but who dedicate their free time to the cultivation of agricultural soil [43]. No incentives were offered to participate in the survey. All participants gave their consent for inclusion before they participated in the study.

\subsection{Instruments}

Participants were verbally informed about the aims of the study and were asked to complete a paper-and-pencil anonymous questionnaire divided into three main sections. Before filling the questionnaire, participants were recommended by a research assistant to refer only to compost obtained from OFMSW, which is compost mainly deriving from food and park residues. In addition, in any part of the questionnaire the reference to this type of compost obtained from OFMSW was specified and the participants were followed by the research assistant in case of need. In the first section of the questionnaire (Table 1), participants were asked to indicate on a four-point scale (1-'never'; 2-'rarely'; 3-'sometimes'; 4 -'often') the frequency of use of different information sources to stay informed and/or to acquire information about OFMSW compost characteristics. Investigated sources included: exhibitions, videos/internet and multimedia sources, journals/advertisement, training 
courses, discussions with peers and discussions with consultants. In the second section, the participants were asked to report their buying habits (quantity of municipal waste compost purchased or obtained free of charge per year, frequency and place of purchase) and to rate their opinion about price perception, preferred packaging format and willingness to pay for certified material (namely the OFMSW compost obtaining a 'quality compost label' after lab testing). In the last section, the participants were asked to indicate, on a four-point scale (1-'strongly disagree'; 2-'disagree'; 3-'agree'; and 4-'strongly agree'), their agreement with factors encouraging OFMSW compost adoption: (1) capability to improve soil fertility and soil structure; (2) reduction of production costs; (3) reduction of environmental impact; (4) availability of official quality certification; (5) availability of experts and consultants to support the application of municipal waste compost; and (6) the availability of subsidies.

Table 1. Questions regarding marketing issues, factors encouraging OFMSW compost adoption, and the rating scales used.

\begin{tabular}{|c|c|c|c|}
\hline Topics & Question & Question Name & Rating Scale \\
\hline Level of information & $1-6$ & $\begin{array}{l}\text { How often do you use the following information } \\
\text { sources to stay informed and/or to acquire } \\
\text { information about compost obtained from } \\
\text { organic fraction of municipal solid waste? } \\
\text { (1. exhibitions; } 2 \text {. videos/internet and } \\
\text { multimedia sources; } 3 \text {. journals/advertisement; } \\
\text { 4. training courses; } 5 \text {. discussions with peers and } \\
\text { 6. discussions with consultants) }\end{array}$ & $\begin{array}{l}\text { Four-point scale } \\
(1=\text { never } ; 4=\text { often })\end{array}$ \\
\hline \multirow[t]{5}{*}{$\begin{array}{l}\text { Personal opinion regarding } \\
\text { marketing issues }\end{array}$} & 7 & $\begin{array}{l}\text { How often do you buy / free of charge } \\
\text { OFMSW compost? }\end{array}$ & $\begin{array}{l}\text { Multiple-choice question: } \\
\text { (1) Once a year; } \\
\text { (2) Twice a year; } \\
\text { (3) Several times a year }\end{array}$ \\
\hline & 8 & $\begin{array}{l}\text { How much OFMSW compost do you buy/free } \\
\text { of charge per year? }\end{array}$ & Open-ended question \\
\hline & 9 & $\begin{array}{l}\text { Where do you usually buy / free of charge } \\
\text { OFMSW compost? }\end{array}$ & $\begin{array}{l}\text { Multiple-choice question: } \\
\text { (1) Composting facility; } \\
\text { (2) Small dealers; } \\
\text { (3) Other }{ }^{1}\end{array}$ \\
\hline & 10 & $\begin{array}{l}\text { How do you judge the price of } \\
\text { OFMSW compost? }\end{array}$ & $\begin{array}{l}\text { Four-point scale } \\
(1=\text { not expensive at all; } 4=\text { too expensive }) \\
\text { Multiple-choice question }\end{array}$ \\
\hline & 12 & $\begin{array}{l}\text { How much are you willing to pay for composted } \\
\text { material obtained from OFMSW? }\end{array}$ & $\begin{array}{l}\text { (1) Less than other soil improvers; } \\
\text { (2) Just like other soil improvers; } \\
\text { (3) More than other soil improvers) } \\
\text { Multiple-choice question: } \\
\text { (1) Unpackaged; } \\
\text { (2) } 5 \mathrm{~kg} \text {; } \\
\text { (3) } 25 \mathrm{~kg} \text {; } \\
\text { (4) } 50 \mathrm{~kg} \text {; } \\
\text { (5) } 500 \mathrm{~kg} \text {; } \\
\text { (6) Other }\end{array}$ \\
\hline
\end{tabular}

How much the following factors can encourage the use of OFMSW compost (1. capability to improve soil fertility and soil

Personal opinion concerning positive factors
13-18 structure; 2 . reduction of production costs; 3 .
reduction of environmentalimpact; 4 . availability of subsidies; 5 . availability of experts and consultants to support the application of municipal waste compost; and 6 . availability of an official quality certification)

\footnotetext{
${ }^{1}$ Participants indicate 'other' when they self-produced the main quantity of compost which they needed.
}

In particular, this last question was used also to understand if participants were aware of the existence of specific measures for income support in the framework of national and regional rural development programs and the European Common Agricultural Policy (CAP). Indeed, the CAP objectives include fostering the competitiveness of agriculture encouraging farmers to invest in soil fertility, maintaining high levels of OM in the soil and promoting the sustainable management of natural resources [44]. Moreover, with regard to Italy, in accordance with a recent national initiative, farms or individuals who purchase 
certified compost obtained from the organic fraction of waste can receive a subsidy, equal to the $25 \%$ of the purchase cost of compost [45]. On the other hand, different regional funding promoted domestic and community self-composting initiatives to encourage the adoption and wider purchase of compost.

A standard socio-demographic form followed to collect information about personal characteristics of the respondents: gender, age, education and occupation. Finally, the participants were asked if they currently keep using OFMSW compost, thus assessing if they were satisfied adopting it.

\subsection{Data Analysis}

Descriptive statistics were computed for all the variables of interest. Due to the small sample size and data not normally distributed, non-parametric Mann-Whitney tests were performed to point out any differences between professional users and hobbyist users in relation to factors encouraging municipal waste compost adoption, willingness to pay, price perception and preferred information sources. Significance was set at $p<0.05$. Statistical analysis was performed using SPSS 26.0 (IBM SPSS Inc., Chicago, IL, USA) software.

\section{Results}

Fifty-four questionnaires were collected. Overall, 41 males and 13 females were involved in the present study, with age ranging from 16 to 79 years (Mean $=45.6$ and $\mathrm{SD}=15.82$ ). The main socio-demographic characteristics of the participants are reported in Table 2. The majority of 'professional' participants were male, mirroring the predominance of male workers among the Italian farming population [46]. Similarly, also among Italian hobbyists, a high percentage are male $[47,48]$. With regard to the cropping systems, 'professionals' mainly grow cereals, fruits, vegetables and grapes, whereas the 'hobbyists' mainly grow herbs, vegetables, and ornamental plants. Only two participants out of 54 (a professional and a hobbyist) had adopted compost made from organic fraction of municipal solid waste only once in the past, while all other participants currently keep using OFMSW compost as organic fertilizer for their crop.

Table 2. Participants' socio-demographic characteristics.

\begin{tabular}{cccc}
\hline Variables & & Professionals & Hobbyists \\
\hline \multirow{2}{*}{ Gender } & Male & \multicolumn{2}{c}{ Frequency $(n)$} \\
& Female & 3 & 24 \\
Education & Middle school & 2 & 10 \\
& Secondary school & 9 & 3 \\
& University & 7 & 14 \\
& Post-university & 1 & 3 \\
\hline Age & \multicolumn{3}{c}{ Mean (SD) } \\
\hline
\end{tabular}

\subsection{Users' Purchasing Patterns and Personal Opinion Regarding Marketing Issues}

When considering questions related the users purchasing behavior, overall, 63\% of participants reported that the most common place where they buy OFMSW compost are small dealers (i.e., stores and garden centers), $29 \%$ prefer to go to composting facilities, whereas, $8 \%$ reported 'other' as a response, specifying that most of the compost they need is self-produced. Taking into account the differences between the two groups, only a few 'hobbyists' (17.4\%) revealed to purchase or obtain gratis compost in composting facilities; vice-versa, almost half of 'professionals' (46.6\%), expressed their preference for composting facilities, claiming also their preference to buy larger quantities of OFMSW compost only once a year ( $40 \%$ of professionals). Overall, with regard to purchasing frequency, $48.5 \%$ of 
all the participants declared buying/free of charge compost only once a year, $27.3 \%$ twice per year, and $24.2 \%$ more than twice per year.

Regarding the quantity of OFMSW compost applied every year, not all participants were able to provide this information. Indeed, only half of them gave an appropriate and reliable response ( $47 \%$ of hobbyists and $55 \%$ of professionals). As expected, significantly different amounts of compost are used by each group: for 'professionals' an average of 87.3 tons (ranging from 4 tons to 500 tons) of compost is required annually, whereas for 'hobbyists' the average amount of OFMSW compost applied per year is approximately $41.3 \mathrm{~kg}$ annually (ranging from $5 \mathrm{~kg}$ to $100 \mathrm{~kg}$ ).

With respect to price perception, the means $(1 \leq \mu \leq 4)$ for the two groups involved were used to discern between low or high price users' perception. Thus, a mean response of $>2.5$ represents the perception of an expensive product, while a mean response of $<2.5$ represents the perception of a cheap product [49]. The mean rate response of participants showed a lower price perception of OFMSW compost among professionals (mean = 2.31) and a higher price perception among hobbyists (mean $=2.50)$; at the same time, although hobbyists perceive OFMSW compost to be more expensive compared to professionals, they would be willing to pay more for certified compost (Table 3). However, statistical analysis showed that between the two groups of users there are no significant differences in terms of price perception, whereas hobbyists reported a significantly higher willingness to extra pay for high-quality compost $(\mathrm{Mdn}=2)(\mathrm{U}=112.00, \mathrm{z}=-2.123, p=0.034)$ compared with professionals $(\mathrm{Mdn}=1)$.

Table 3. Percentage of responses on price perception and willingness to pay.

\begin{tabular}{cccccc}
\hline \multicolumn{3}{c}{ Price Perception ${ }^{1}$} & \multicolumn{3}{c}{ Willingness to Pay } \\
\hline & \multicolumn{3}{c}{ Frequency (\%) } \\
Professionals & High & Low & Less & Equal & More \\
Hobbyists & 47.5 & 62.5 & 53.3 & 46.7 & 0 \\
\end{tabular}

${ }^{1}$ The Likert scale was recoded to a dichotomous variable [50]. Likert scale with categories 'not at all expensive', 'few expensive', 'expensive', 'too much expensive', was recoded to a dichotomous variable. Categories 'not at all expensive' and 'few expensive' were recoded to 'low price perception' and the categories of 'expensive' and 'too much expensive' were recoded to 'high price perception'.

Regarding data on the packaging format that users would like to find on sale, the majority of hobbyist participants preferred small and medium-size packaging, while a few others expressed their preference of buying compost in bulk. However, participants did not explicitly mention the quantity of OFMSW compost they are used to buy from time to time in case of bulk product. Regarding professionals, even though nearly half of them prefer to buy compost in bulk, the majority of them expressed the preference to buying OFMSW compost in bags of $500 \mathrm{~kg}$. Results are shown in Table 4.

Table 4. Percentage of responses on purchasing behavior.

\begin{tabular}{|c|c|c|c|c|c|c|c|c|}
\hline & \multicolumn{3}{|c|}{ Place Where Shop } & \multirow{2}{*}{\multicolumn{2}{|c|}{$\begin{array}{l}\text { Purchase Frequency }{ }^{1} \\
\text { Frequency (\%) }\end{array}$}} & \multicolumn{3}{|c|}{ Packaging Format ${ }^{1}$} \\
\hline & & & & & & & & \\
\hline & Composting facility & Otherdealers & Other $^{2}$ & Once a year & More times & Unpackaged & $\begin{array}{c}\text { Small } \\
(<500 \mathrm{~kg})\end{array}$ & $\begin{array}{c}\text { Large } \\
(\geq 500 \mathrm{~kg})\end{array}$ \\
\hline Professionals & 46.6 & 33.4 & 20.0 & 61.5 & 38.5 & 43.8 & 0.0 & 56.8 \\
\hline Hobbysts & 17.4 & 82.6 & 0.0 & 40.0 & 60.0 & 29.2 & 70.8 & 0.0 \\
\hline
\end{tabular}

1 The original scales in the questionnaire were collapsed in the table: under 'purchase frequency' column 'more times' includes 'twice a year', and 'several times a year'; whereas under 'packaging format' column the class 'small (<500 kg)' includes $5 \mathrm{~kg}$, $25 \mathrm{~kg}$, and $50 \mathrm{~kg}$; and 'unpackaged' includes 'other' undefined quantities. ${ }^{2}$ Participants indicated that they self-produced the main quantity of compost they needed. 


\subsection{Users' Preferences for Information Sources}

The data collected showed that participants search for information about OFMSW compost and application more often from impersonal sources such as multimedia channels (videos and internet), journal and advertisement, whereas, when considering personal communication sources, participants express their preference for discussions with peers (friends, neighbors, or colleagues).

Differences between the two groups of users are reported in Figure 1. When looking at the differences among the two groups, the Mann-Whitney U-test showed that professionals make a greater use of discussions with peers $(\mathrm{Mdn}=3)(\mathrm{U}=219.50, \mathrm{z}=0.2 .217, p=0.027)$ and discussions with consultants as information sources $(\mathrm{Mdn}=3)(\mathrm{U}=228.00, \mathrm{z}=-2.029$, $p=0.045)$ compared with the hobbyists (respectively Mdn = 2 and Mdn =1). Overall, professionals reported a greater propensity to keep themselves informed $(\mathrm{Mdn}=14.5)$ $(\mathrm{U}=214.50, \mathrm{z}=-1.997, p=0.046)$ compared with hobbyists $(\mathrm{Mdn}=12.00)$.

\subsection{Factors Encouraging the OFMSW Compost Adoption}

The main perceived benefits of using compost from organic fraction of municipal solid waste are related to its low environmental impact and capability to improve soil characteristics. In contrast, the availability of subsidies was not reported as a particular relevant factor able to encourage users to purchase and use the municipal waste compost, maybe because of the lack of knowledge about the existence of such subsidies. The mean scores reported for the availability of subsidies were 1.89 and 2.05 for professionals and hobbyists respectively (Figure 2). The Mann-Whitney test showed that hobbyists perceived significantly higher benefits from the capability of compost to reduce the costs of crop production $(\mathrm{Mdn}=4)(\mathrm{U}=10.00, \mathrm{z}=-2.310, p=0.029)$ compared with professionals ( $\mathrm{Mdn}=2)$. No significant differences emerged between the two groups regarding other encouraging factors investigated. However, professionals reported a higher overall propensity to consider compost as more beneficial $(\mathrm{Mdn}=19.82)$ compared with hobbyists $(\mathrm{Mdn}=15.84)$ even though the difference was not statistically significant. 


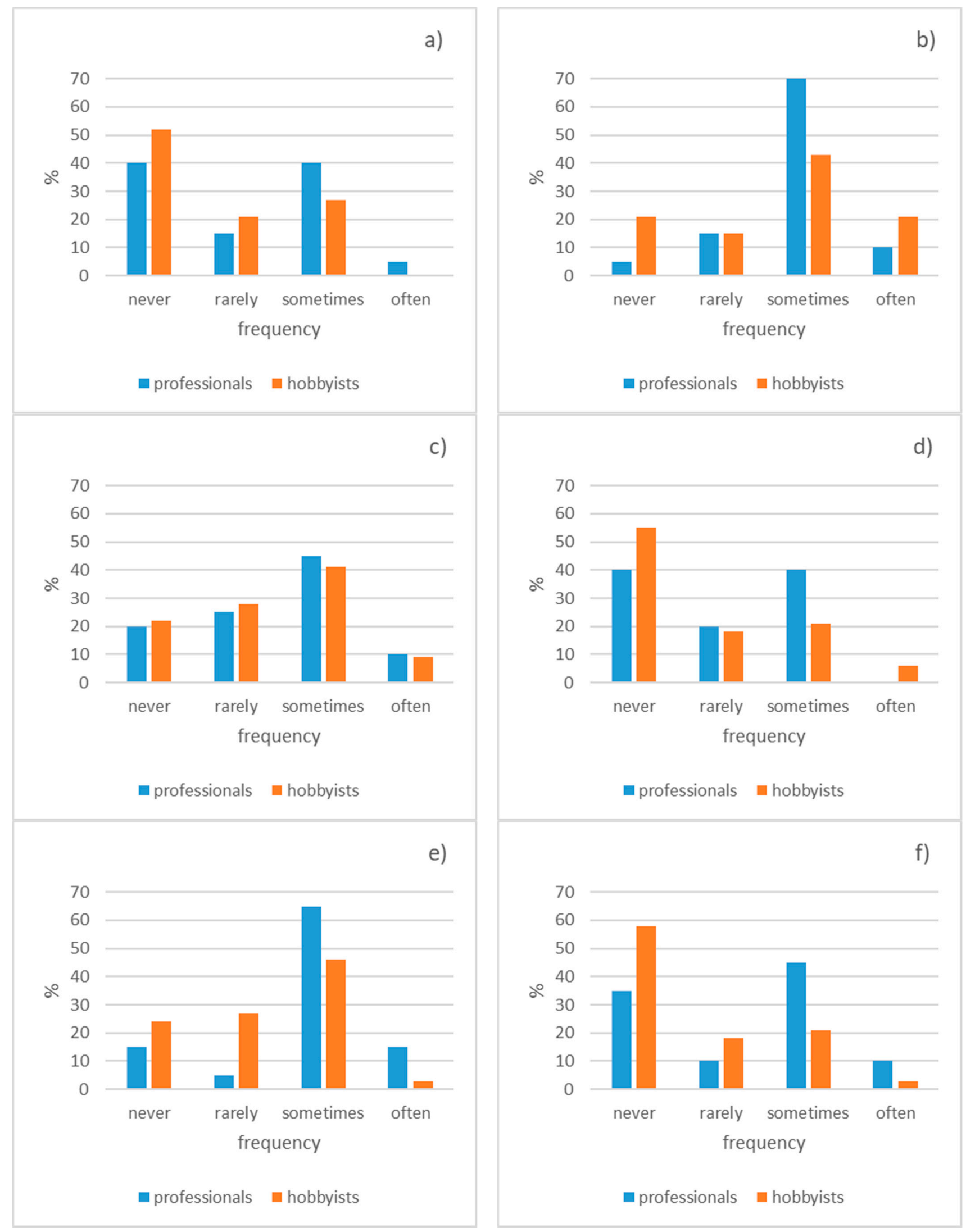

Figure 1. Frequency of use of different information sources reported by participants: (a) exhibitions, (b) videos and internet, (c) journals and advertisement, (d) training courses, (e) discussions with peers, and (f) discussions with consultants. 


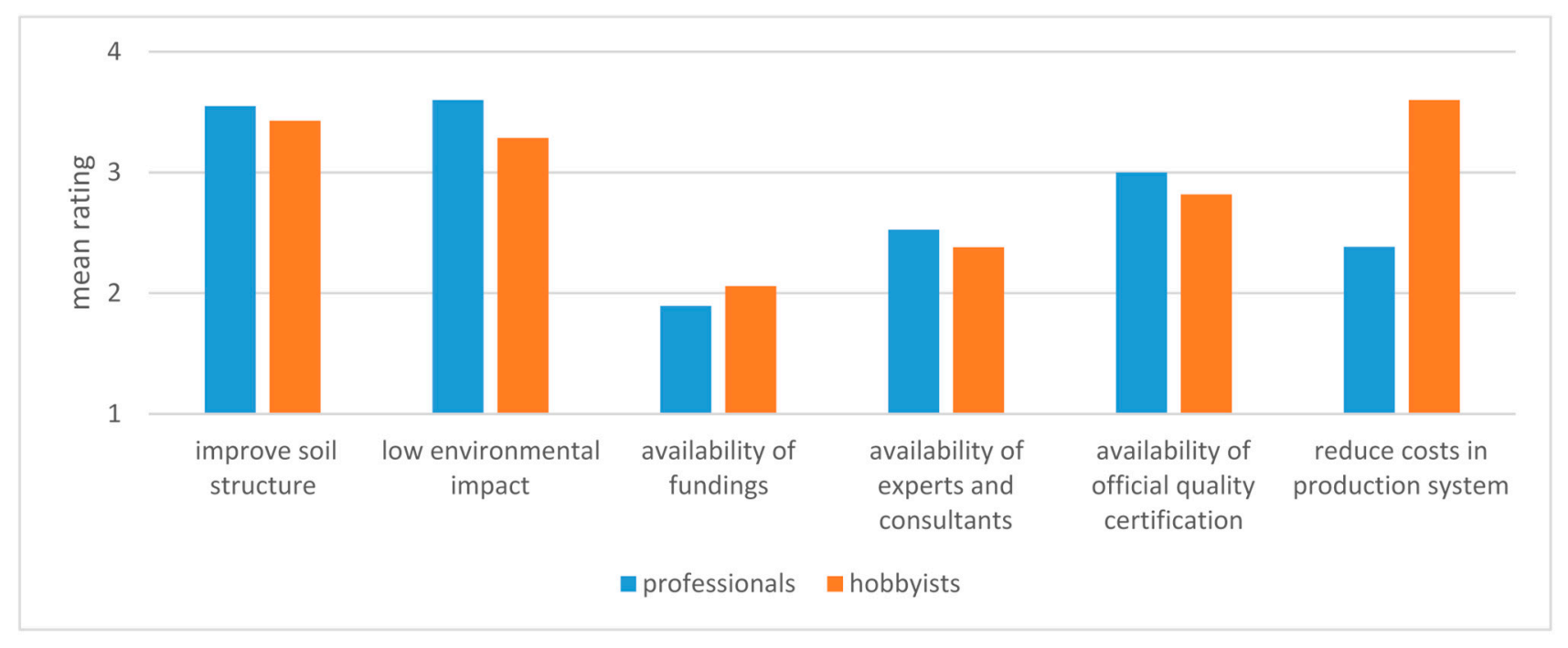

Figure 2. Mean rate regarding benefits of using OFMSW compost in the two groups of participants.

\section{Discussion}

Previous research investigated users' perception of fertilizers and soil improvers in terms of nutrients and inherent characteristics, especially among farmers and expert operators $[26,28,51]$, while some others have paid attention to the users' point of view about marketing aspects [52,53]. Even fewer studies focused on municipal waste compost perception from both professionals and hobbyists. Moreover, to our knowledge, the extant literature does not examine together the marketing issues and the purchasing behavior as considered in this study, for different categories of users. By understanding similarities and differences between professionals and hobbyists, the present study aimed to provide some useful information and discuss practicable tips for improving marketing and communication strategies seeking to expand municipal waste compost sales.

First of all, as expected the professionals and the hobbyists involved highlighted different needs and behaviors towards the investigated product: similarly to previous studies, hobbyists prefer to buy composted material mainly from small dealers, maybe because they can offer a good quality-price ratio and because customers feel they can receive better advice and a more personalized service [52,54]. Consistently with our results, Andersen et al. [54] reported also that most professionals prefer to buy compost from recycling centers once or twice a year, adopting a tractor and trailer for transportation since they buy larger quantities of compost. In addition, the packaging format could affect the decision-making process during the purchasing of municipal waste compost. The outcome of the present study is consistent with some previous studies, in which smaller consumers (hobbyists) declared to prefer small or medium-size packaging of the product (ranging from $10 \mathrm{~kg}$ to $75 \mathrm{~kg}$ [52]).

Considering the economic aspects, similarly to Siddiqui et al. [55], customers' willingness to pay for a more expensive certified compost has proved to be different between the two groups of users considered. This could be explained by considering the farm size of professionals [55] and the different amounts of OFMSW compost required from each category of users, since larger quantities needed correlate with higher attention to prices and quality-price ratio [52,55]. Based on this, farmers could opt for a less expensive product. However, in the present study, many hobbyist users reported buying high amount of OFMSW compost (i.e., $100 \mathrm{~kg}$ ). This data is probably due to the fact that in Italy the activity of hobbyists, and in particular of hobby farmers, is carried out in fields characterized by a non-negligible average extent. Indeed, in Italy nearly the $64 \%$ of hobbyists have up to 0.6 hectares of field surface, and even $24 \%$ own fields larger than one hectare [47].

However, for hobbyists the willingness to pay 'extra' for certified products could be linked with their need to feel environmentally virtuous and feel better about their 
action [56]. Based on this, further studies should investigate the users' differences in perception about today's severe ecological problems and their behavior toward products with CE certification as compared to an uncertified product [57]. Probably, focusing on the communication of the circular principles of municipal waste compost could be a significant advantage for compost producers.

Nowadays, a wide range of multimedia and non-multimedia channels are used to convey several marketing communications [58]. Marketing experts themselves are not able to understand precisely which communication strategies and which types of messages are more effective than others and which ones could involve a broader target audience [59]. Managing all the information flows is a complex challenge, but it could help users to structure their environment, take decisions, ascribe meaning and act more consciously toward a circular consumption $[60,61]$. However, it is important to bear in mind that information sources need to be credible, reliable and familiar [62]. Our results related to information sources about municipal compost adoption are consistent with the overall results from previous studies dealing with the introduction of a new cropping strategy or a new organic soil improver. Professionals usually prefer personal information sources and discussions with relatives, neighbors, and other experts [63-65] probably because they prefer to listen, talk and share their knowledge rather than spend too much time reading $[65,66]$. However, when users need to choose a specific fertilizer, the present results are in contrast with those reported by $[67,68]$, since they reported that farmers turn mainly to cooperatives and companies, whereas peers and neighbors are not particularly considered. Regarding CE communication strategies [69], have previously identified some effective methods to influence the adoption or acceptance of circular products and services. In the specific case of compost utilization, peer testimonials, storytelling, metaphors, or playfulness messages can be used to try to change and/or reinforce users' preconceptions about recycled products. For instance, defining the second life materials as 'rescued' or 'heroic' can help users to change their minds with respect to initial feelings of disgust or fear of contamination from a pre-used material. Moreover, peer-to-peer information and knowledge sharing play a key-role in transition to a circular model of economy. Therefore, the current farmers' behavior and in particular, peer testimonials about the compost advantages, could reinforce this positive network [70] between compost producers and users.

Finally, with respect to the perceived advantages of compost obtained from the organic fraction of municipal solid waste, respondents to the survey perceived as the main benefits related with OFMSW compost adoption the properties to improving soil structure, sanitizing from weeds and pathogens and increasing resistance against diseases and dryness, similarly to the results reported by [71,72]. On the opposite, the study highlighted that the availability of subsidies does not represent a determining factor that encourages users to compost adoption. This suggests that, among the current users, the existence of subsidy not necessarily affects the use of OM or compost [73], because users recognize compost nutritive characteristics and the benefits that it can supply to the soil, a far more important factor. However, it could be also supposed that low consideration of subsidies can represent a limiting factor in the use of larger amounts of compost [72].

Some limitations of the present study need to be acknowledged. We were aware that involving participants during exhibitions may lead to a self-selection bias [74]. In addition, obtained results cannot be generalized since the study involved a small sample size in a specific context. Nevertheless, the study is still interesting because it focused on the perceptions of two main categories of potential large-volume users of compost. Future studies, taking into account other factors affecting the purchasing behavior are recommended. For instance, investigating if the distance from the principal OFMSW compost supplier considerably affects buyers' behavior could provide additional relevant information useful to expand the compost market and better promote it within the nearby stores. Moreover, future studies should involve a larger sample of participants, both male 
and female, for instance to investigate gender issue and also focusing on perceived barriers and drivers in OFMSW compost adoption.

\section{Conclusions}

The adoption of compost from organic fraction of municipal solid waste is not widespread in many European countries. However, from results reported in the present study seems that users who already adopt OFMSW compost keep using it since they perceive several advantages from its utilization. Indeed, in accordance with studies about the marketing of food products, once users are satisfied with a given product, they tend to use it again [75]. The present study highlighted some users' purchasing preferences and the preferred sources of information to obtain information on compost made from municipal waste. Based on these, to reach some specific categories of users, marketers need to adopt targeted communication campaigns, focusing on the positive compost features, environmental aspects, and also aiming at the promotion of subsidies, if available.

Finally, the broader use of personal communication between different users, and in particular between peers and experts, may have influenced the adoption and perception on compost. People exert social influence in different ways and they may influence each other through conversation [76]. Thus, social influence can promote sustainable behavior and encourage the CE business model-pointing out the role played by users within a social, cultural, ethical, and environmental context-because users' purchasing choices can largely contribute to make societies more sustainable.

Author Contributions: Conceptualization, L.V., N.P. and E.C.; Data curation, L.V. and G.B.; Formal analysis, L.V.; Investigation, L.V., N.P. and G.B.; Methodology, L.V., N.P. and G.B.; Project administration, E.C.; Writing—original draft, L.V.; Writing—review and editing, N.P., G.B. and E.C. All authors have read and agreed to the published version of the manuscript.

Funding: This research received no external funding.

Data Availability Statement: Not applicable.

Acknowledgments: Research reported in this publication was supported by GAIA Spa (Gestione Ambientale Integrata dell'Astigiano).

Conflicts of Interest: The authors declare no conflict of interest.

\section{References}

1. Haastrup, P.; Maniezzo, V.; Mattarelli, M.; Rinaldi, F.M.; Mendes, I.; Paruccini, M. A decision support system for urban waste management. Eur. J. Oper. Res. 1998, 109, 330-341. [CrossRef]

2. ISPRA (Istituto Superiore per la Protezione e Ricerca Ambientale). Rapporto rifiuti urbani. Edizione 2017. Estratto; 2017. Available online: http://www.isprambiente.gov.it/files2017/pubblicazioni/rapporto/RapportoRifiutiUrbani_Ed.2017n.273_ Vers.Estratto_agg06_11_2017.pdf (accessed on 21 June 2021).

3. European Commission. Proposta di Direttiva del Parlamento Europeo e del Consiglio che Modifica la Direttiva 94/62/CE Sugli Imballaggi e i Rifiuti di Imballaggio; Proposal for a directive of the European parliament and of the council amending Directive 94/62/EC on packaging; European Commission: Brussel, Belgium, 2015; Available online: https:/ / eur-lex.europa.eu/resource.html?uri=cellar: b68494d2-999f-11e5-b3b7-01aa75ed71a1.0019.02/DOC_1\&format=PDF (accessed on 21 June 2021).

4. Jørgensen, S.; Pedersen, L.J.T. Why Sustainable Business Model Innovation? In Restart Sustainable Business Model Innovation; Palgrave Macmillan: London, UK, 2018; Chapter 1; pp. 3-11. Available online: https://link.springer.com/content/pdf/10.1007\% 2F978-3-319-91971-3.pdf (accessed on 21 June 2021). [CrossRef]

5. Lofthouse, V.; Prendeville, S. Human-Centred Design of Products and Services for the Circular Economy-A Review. Des. J. 2018, 21, 451-476. [CrossRef]

6. Haggar, S.E. Sustainable Industrial Design and Waste Management: Cradle-to-Cradle for Sustainable Development; Academic Press: Cambridge, MA, USA, 2010.

7. Song, Q.; Li, J.; Zeng, X. Minimizing the increasing solid waste through zero waste strategy. J. Clean. Prod. 2015, 104, 199-210. [CrossRef]

8. Kirchherr, J.; Reike, D.; Hekkert, M. Conceptualizing the circular economy: An analysis of 114 definitions. Resour. Conserv. Recycl. 2017, 127, 221-232. [CrossRef]

9. Fondazione Symbola. 100 Italian Circular Economy Stories 2018:220. Available online: https://circulareconomy.europa.eu/ platform/sites/default/files/100storie_def_web_pag_singole_25-05-18_1527247969.pdf (accessed on 21 June 2021). 
10. Korhonen, J.; Honkasalo, A.; Seppälä, J. Circular Economy: The Concept and its Limitations. Ecol. Econ. 2018, 143, 37-46. [CrossRef]

11. Bekchanov, M.; Mirzabaev, A. Circular economy of composting in Sri Lanka: Opportunities and challenges for reducing waste related pollution and improving soil health. J. Clean. Prod. 2018, 202, 1107-1119. [CrossRef]

12. Paritosh, K.; Yadav, M.; Mathur, S.; Balan, V.; Liao, W.; Pareek, N.; Vivekanand, V. Organic Fraction of Municipal Solid Waste: Overview of Treatment Methodologies to Enhance Anaerobic Biodegradability. Front. Energy Res. 2018, 6, 1-17. [CrossRef]

13. Espinosa-Salgado, R.; Saucedo-Castañeda, G.; Monroy-Hermosillo, O.; Metropolitana, U.A. Composting a digestate from the organic fraction of urban solid wastes. Rev. Mex. Ing. Química 2020, 19, 1-8. [CrossRef]

14. Jara-Samaniego, J.; Pérez-Murcia, M.; Bustamante, M.; Pérez-Espinosa, A.; Paredes, C.; López, M.; López-Lluch, D.; GavilanesTerán, I.; Moral, R. Composting as sustainable strategy for municipal solid waste management in the Chimborazo Region, Ecuador: Suitability of the obtained composts for seedling production. J. Clean. Prod. 2017, 141, 1349-1358. [CrossRef]

15. Rahmani, M.; Hodges, A.W.; Kiker, C.F. Compost Users' Attitudes Toward Compost Application in Florida. Compos. Sci. Util. 2004, 12, 55-60. [CrossRef]

16. Vlachokostas, C.; Achillas, C.; Diamantis, V.; Michailidou, A.V.; Baginetas, K.; Aidonis, D. Supporting decision making to achieve circularity via a biodegradable waste-to-bioenergy and compost facility. J. Environ. Manag. 2021, 285, 112215. [CrossRef]

17. Nolan, T.; Troy, S.M.; Healy, M.; Kwapinski, W.; Leahy, J.J.; Lawlor, P.G. Characterization of compost produced from separated pig manure and a variety of bulking agents at low initial C/N ratios. Bioresour. Technol. 2011, 102, 7131-7138. [CrossRef] [PubMed]

18. Pampuro, N.; Bisaglia, C.; Romano, E.; Brambilla, M.; Pedretti, E.F.; Cavallo, E. Phytotoxicity and Chemical Characterization of Compost Derived from Pig Slurry Solid Fraction for Organic Pellet Production. Agriculture 2017, 7, 94. [CrossRef]

19. Jakobs, I.; Schmittmann, O.; Athmann, M.; Kautz, T.; Lammers, P.S.; Lammers, S. Cereal Response to Deep Tillage and Incorporated Organic Fertilizer. Agronomy 2019, 9, 296. [CrossRef]

20. Kakabouki, I.; Folina, A.; Efthimiadou, A.; Karydogianni, S.; Zisi, C.; Kouneli, V.; Kapsalis, N.C.; Katsenios, N.; Travlos, I. Evaluation of Processing Tomato Pomace after Composting on Soil Properties, Yield, and Quality of Processing Tomato in Greece. Agronomy 2021, 11, 88. [CrossRef]

21. Parkinson, R. Effect of turning regime and seasonal weather conditions on nitrogen and phosphorus losses during aerobic composting of cattle manure. Bioresour. Technol. 2004, 91, 171-178. [CrossRef]

22. Chrysargyris, A.; Saridakis, C.; Tzortzakis, N. Use of Municipal Solid Waste Compost as Growing Medium Component for Melon Seedlings Production. J. Plant Biol. Soil Health 2013, 2, 1-5.

23. Civeira, G. Influence of Municipal Solid Waste Compost on Soil Properties and Plant Reestablishment in Peri-Urban Environments Chil. J. Agric. Res. 2010, 70, 446-453. [CrossRef]

24. Pampuro, N.; Bertora, C.; Sacco, D.; Dinuccio, E.; Grignani, C.; Balsari, P.; Cavallo, E.; Bernal, M.P. Fertilizer value and greenhouse gas emissions from solid fraction pig slurry compost pellets. J. Agric. Sci. 2017, 155, 1646-1658. [CrossRef]

25. Papamichalaki, M.; Papadaki, A.; Tzortzakis, N. Substitution of peat with municipal solid waste compost in watermelon seedling production combined with fertigation. Chil. J. Agric. Res. 2014, 74, 452-459. [CrossRef]

26. Pampuro, N.; Preti, C.; Cavallo, E. Recycling Pig Slurry Solid Fraction Compost as a Sound Absorber. Sustainability 2018, 10, 277. [CrossRef]

27. Paul, J.; Sierra, J.; Causeret, F.; Guindé, L.; Blazy, J.-M. Factors affecting the adoption of compost use by farmers in small tropical Caribbean islands. J. Clean. Prod. 2017, 142, 1387-1396. [CrossRef]

28. Case, S.; Oelofse, M.; Hou, Y.; Oenema, O.; Jensen, L. Farmer perceptions and use of organic waste products as fertilisers-A survey study of potential benefits and barriers. Agric. Syst. 2017, 151, 84-95. [CrossRef]

29. Barboza, J.C.; Morales, H.; Barrantes, R.A.; Moreno, A.S.; Lwanga, E.H. Perceptions and attitudes regarding organic waste: Feasibility of establishing an urban composting program in Chiapas, Mexico. J. Agric. Food Syst. Community Dev. 2011, 1, 115-131. [CrossRef]

30. Budijati, S.M.; Subagyo, N.; Wibisono, M.A.; Masruroh, N.A. The influence of environmental attitude on consumers' intentions to participate in a take back program. Int. J. Logist. Syst. Manag. 2017, 26, 421. [CrossRef]

31. Tamas, A.; Mosler, H.-J.; Tobias, R.; Caballero Rodríguez, T.; Guzmán Miranda, O. Factors Determining the Intentions to Reuse, Separate and Compost Household Waste in the City of Santiago De Cuba. Waste Soc. Context 2005, 2005, 736-744.

32. Rousta, K.; Zisen, L.; Hellwig, C. Household Waste Sorting Participation in Developing Countries-A Meta-Analysis. Recycling 2020, 5, 6. [CrossRef]

33. European Commission. Esempi di Successo sul Compostaggio e la Raccolta Differenziata [Success Stories on Composting and Separate Collection]; European Commission: Lussemburg, Belgium, 2000.

34. Viaene, J.; Van Lancker, J.; Vandecasteele, B.; Willekens, K.; Bijttebier, J.; Ruysschaert, G.; De Neve, S.; Reubens, B. Opportunities and barriers to on-farm composting and compost application: A case study from northwestern Europe. Waste Manag. 2016, 48, 181-192. [CrossRef] [PubMed]

35. Dahlin, J.; Beuthner, C.; Halbherr, V.; Kurz, P.; Nelles, M.; Herbes, C. Sustainable compost and potting soil marketing: Private gardener preferences. J. Clean. Prod. 2019, 208, 1603-1612. [CrossRef]

36. Hou, Y.; Velthof, G.; Case, S.; Oelofse, M.; Grignani, C.; Balsari, P.; Zavattaro, L.; Gioelli, F.; Bernal, M.; Fangueiro, D.; et al. Stakeholder perceptions of manure treatment technologies in Denmark, Italy, The Netherlands and Spain. J. Clean. Prod. 2018, 172, 1620-1630. [CrossRef] 
37. Zhou, Y.; Zhou, Q.; Gan, S.; Wang, L. Factors affecting farmers' willingness to pay for adopting vegetable residue compost in North China. Acta Ecol. Sin. 2018, 38, 401-411. [CrossRef]

38. Centemero, M.; Caimi, V.; Adani, F.; Compostatori, C.I. L'impiego del Compost in Agricoltura "The Use of Compost in Agriculture". Available online: https://www.researchgate.net/publication/238682407_L\%27IMPIEGO_DEL_COMPOST_IN_ AGRICOLTURA_THE_USE_OF_COMPOST_IN_AGRICULTURE (accessed on 21 June 2021).

39. Reichardt, M.; Jürgens, C. Adoption and future perspective of precision farming in Germany: Results of several surveys among different agricultural target groups. Precis. Agric. 2009, 10, 73-94. [CrossRef]

40. Caffaro, F.; Cremasco, M.M.; Roccato, M.; Cavallo, E. It does not occur by chance: A mediation model of the influence of workers' characteristics, work environment factors, and near misses on agricultural machinery-related accidents. Int. J. Occup. Environ. Health 2017, 23, 52-59. [CrossRef]

41. Jones, R.; Wham, C.; Burlingame, B. New Zealand's Food System Is Unsustainable: A Survey of the Divergent Attitudes of Agriculture, Environment, and Health Sector Professionals Towards Eating Guidelines. Front. Nutr. 2019, 6, 99. [CrossRef]

42. Roelofsen, A.; Broerse, J.; Buning, T.D.C.; Bunders, J. Engaging with future technologies: How potential future users frame ecogenomics. Sci. Public Policy 2010, 37, 167-179. [CrossRef]

43. Pantini, D.; Spigola, M. Il Fenomeno Dell' Hobby Farming in Italia: Evidenze e Prospettive. Agriregionieuropa. 2010, pp. 1-6. Available online: https://agriregionieuropa.univpm.it/it/content/article/31/21/lhobby-farming-italia-evidenze-e-prospettive (accessed on 21 June 2021).

44. European Commission. The Common Agricultural Policy at a Glance. The Common Agricultural Policy Supports Farmers and Ensures Europe's Food Security. 2019. Available online: https:/ /ec.europa.eu/info/food-farming-fisheries/key-policies/ common-agricultural-policy / cap-glance_en (accessed on 21 June 2021).

45. DL 34/19. Decree-Law No 34/19-Conversione in Legge, con Modificazioni, del Decreto-Legge 30 Aprile 2019, n. 34, Recante Misure Urgenti di Crescita Economica e per la Risoluzione di Specifiche Situazioni di Crisi. Gazzetta Ufficiale della Repubblica Italiana. Supplemento Ordinario alla “Gazzetta Ufficiale n. 151 del 29 giugno 2019_Serie Generale; 2019. Available online: https:/ / www.agenziacoesione.gov.it/wp-content/uploads/2019/07/Legge-58_2019-Crescita-testo-integrale-GU.pdf (accessed on 21 June 2021).

46. CREA (Consiglio Per La Ricerca In Agricoltura E L'analisi Dell'economia Agraria). Annuario DELL'AGRICOLTURA ITALIANA 2017. 2019. Available online: https://www.crea.gov.it/documents /68457/0/Annuario_2017+\%281\%29.pdf/1fd6e07f-268e-98 2e-b8ae-7acf9c5f6911?t=1579705767599 (accessed on 21 June 2021).

47. Nomisma. XI Rapporto Nomisma Sull'agricoltura Italiana. La Competitività Dell'agricoltura Italiana di Fronte ai Nuovi Scenari Evolutivi; Publisher Il Sole 24 Ore Edagricole: Milano, Italy, 2008; p. 352.

48. Coldiretti. Caldo: Coldiretti, 20 Mln di Italiani in Orti, Giardini e Terrazzi 2017. Available online: https://www.coldiretti.it/ economia/caldo-coldiretti-20-mln-di-italiani-in-orti-giardini-e-terrazzi (accessed on 21 June 2021).

49. Simha, P.; Lalander, C.; Vinneras, B.; Ganesapillai, M. Farmer attitudes and perceptions to the re-use of fertiliser products from resource-oriented sanitation systems-The case of Vellore, South India. Sci. Total Environ. 2017, 581-582, 885-896. [CrossRef]

50. Telfer, B.; Rissel, C.; Bindon, J.; Bosch, T. Encouraging cycling through a pilot cycling proficiency training program among adults in central Sydney. J. Sci. Med. Sport 2006, 9, 151-156. [CrossRef]

51. Huttunen, S.; Oosterveer, P. Transition to Sustainable Fertilisation in Agriculture, A Practices Approach. Sociol. Rural. 2016, 57, 191-210. [CrossRef]

52. Dahlin, J.; Nelles, M.; Herbes, C. Biogas digestate management: Evaluating the attitudes and perceptions of German gardeners towards digestate-based soil amendments. Resour. Conserv. Recycl. 2017, 118, 27-38. [CrossRef]

53. Dawson, G.F.; Probert, E.J. Commitment: The Case of Green Waste in Wales. Sustain. Dev. 2007, 82, 69-82. [CrossRef]

54. Andersen, J.K.; Christensen, T.H.; Scheutz, C. Substitution of peat, fertiliser and manure by compost in hobby gardening: User surveys and case studies. Waste Manag. 2010, 30, 2483-2489. [CrossRef] [PubMed]

55. Siddiqui, K.; Ahmed, R. Fertilizer Branding in Pakistan. Int. J. Mark Technol. 2013, 3, 82-92.

56. Boyer, R.H.; Hunka, A.D.; Linder, M.; Whalen, K.A.; Habibi, S. Product Labels for the Circular Economy: Are Customers Willing to Pay for Circular? Sustain. Prod. Consum. 2021, 27, 61-71. [CrossRef]

57. Laroche, M.; Bergeron, J.; Barbaro-Forleo, G. Targeting consumers who are willing to pay more for environmentally friendly products. J. Consum. Mark. 2001, 18, 503-520. [CrossRef]

58. Danaher, P.J.; Rossiter, J.R. Comparing perceptions of marketing communication channels. Eur. J. Mark. 2011, 45, 6-42. [CrossRef]

59. Ashley, C.; Tuten, T. Creative Strategies in Social Media Marketing: An Exploratory Study of Branded Social Content and Consumer Engagement. Psychol. Mark. 2015, 32, 15-27. [CrossRef]

60. Camacho-Otero, J.; Tunn, V.S.; Chamberlin, L.; Boks, C. Consumers in the circular economy. In Handbook of the Circular Economy; Edward Elgar Publishing: Cheltenham, UK, 2020; Volume 4, pp. 74-87. [CrossRef]

61. Zeweld, W.; Van Huylenbroeck, G.; Tesfay, G.; Speelman, S. Smallholder farmers' behavioural intentions towards sustainable agricultural practices. J. Environ. Manag. 2017, 187, 71-81. [CrossRef] [PubMed]

62. Opara, U.N. Agricultural Information Sources Used by Farmers in Imo State, Nigeria. Inf. Dev. 2008, 24, 289-295. [CrossRef]

63. Ford, S.A.; Babb, E.M. Farmer sources and uses of information. Agribusiness 1989, 5, 465-476. [CrossRef]

64. Martini, E.; Roshetko, J.M.; Paramita, E. Can farmer-to-farmer communication boost the dissemination of agroforestry innovations? A case study from Sulawesi, Indonesia. Agrofor. Syst. 2017, 91, 811-824. [CrossRef] 
65. Msoffe, G.E.; Ngulube, P. Information sources preference of poultry farmers in selected rural areas of Tanzania. J. Libr. Inf. Sci. 2017, 49, 82-90. [CrossRef]

66. Bruening, T.; Radhakrishna, R.B.; Rollins, T.J. Environmental issues: Farmers' perceptions about usefulness of informational and organizational sources. J. Agric. Educ. 1992, 33, 34-42. [CrossRef]

67. Hartke, D. Producers still prefer print, Gallup study shows. AgriMarketing 2001, 39, 74.

68. Tucker, M.; Napier, T.L. Preferred sources and channels of soil and water conservation information among farmers in three midwestern US watersheds. Agric. Ecosyst. Environ. 2002, 92, 297-313. [CrossRef]

69. Chamberlin, L.; Boks, C. Marketing Approaches for a Circular Economy: Using Design Frameworks to Interpret Online Communications. Sustainability 2018, 10, 2070. [CrossRef]

70. Urbinati, A.; Chiaroni, D.; Chiesa, V. Towards a new taxonomy of circular economy business models. J. Clean. Prod. 2017, 168, 487-498. [CrossRef]

71. Danso, G.; Drechsel, P.; Fialor, S.; Giordano, M. Estimating the demand for municipal waste compost via farmers' willingness-topay in Ghana. Waste Manag. 2006, 26, 1400-1409. [CrossRef]

72. Walker, P.; Williams, D.; Waliczek, T.M. An Analysis of the Horticulture Industry as a Potential Value-Added Market for Compost. Compos. Sci. Util. 2006, 14, 23-31. [CrossRef]

73. Morgan, S.N.; Mason, N.M.; Levine, N.K.; Zulu-Mbata, O. Dis-incentivizing sustainable intensification? The case of Zambia's maize-fertilizer subsidy program. World Dev. 2019, 122, 54-69. [CrossRef]

74. McBurney, D.; White, T. Research Methods, 8th ed.; Cengage Learn: Belmont, CA, USA; Wadsworth, OH, USA, 2010 ; p. 129.

75. Consiglio, I.; Kupor, D.M.; Gino, F.; Norton, M.I. Brand (in)fidelity: When Flirting with the Competition Strengthens Brand Relationships. J. Consum. Psychol. 2017, 28, 5-22. [CrossRef]

76. Goldsmith, E.B.; Goldsmith, R.E. Social influence and sustainability in households. Int. J. Consum. Stud. 2011, 35, 117-121. [CrossRef] 